\title{
Correction to: On the Difference Between the Tensile Stiffness of Bulk and Slice Samples of Microstructured Materials
}

\author{
Rainer Glüge ${ }^{1} \mathbb{D} \cdot$ Holm Altenbach $^{2} \cdot$ Nasir Mahmood $^{3} \cdot$ Mario Beiner $^{3}$
}

Published online: 11 October 2021

(c) The Author(s) 2021

\section{Correction to: Applied Composite Materials (2020) 27:969-988 https://doi.org/10.1007/s10443-020-09833-3}

The article "On the Difference Between the Tensile Stiffness of Bulk and Slice Samples of Microstructured Materials", written by Glüge, R., Altenbach, H., Mahmood, N., and Beiner, M., was originally published Online First without Open Access. After publication in volume 27, issue 6, pages 969-988 the author decided to opt for Open Choice and to make the article an Open Access publication. Therefore, the copyright of the article has been changed to () The Author(s) 2020 and the article is forthwith distributed under the terms of the Creative Commons Attribution 4.0 International License, which permits use, sharing, adaptation, distribution and reproduction in any medium or format, as long as you give appropriate credit to the original author(s) and the source, provide a link to the Creative Commons licence, and indicate if changes were made. The images or other third party material in this article are included in the article's Creative Commons licence, unless indicated otherwise in a credit line to the material. If material is not included in the article's Creative Commons licence and your intended use is not permitted by statutory regulation or exceeds the permitted use, you will need to obtain permission directly from the copyright holder. To view a copy of this licence, visit http://creativecommons.org/licenses/by/4. 0/. Open Access funding enabled and organized by Projekt DEAL.

The original article can be found online at https://doi.org/10.1007/s10443-020-09833-3.

Rainer Glüge

gluege@uni-bremen.de

Holm Altenbach

holm.altenbach@ovgu.de

Nasir Mahmood

nasir.mahmood@imws.fraunhofer.de

Mario Beiner

mario.beiner@imws.fraunhofer.de

1 University of Bremen, Bremen, Germany

2 Otto-von-Guericke-University, Magdeburg, Germany

3 Fraunhofer Institute for Microstructure of Materials and Systems IMWS, Halle, Germany 
The original article has been corrected.

Open Access This article is licensed under a Creative Commons Attribution 4.0 International License, which permits use, sharing, adaptation, distribution and reproduction in any medium or format, as long as you give appropriate credit to the original author(s) and the source, provide a link to the Creative Commons licence, and indicate if changes were made. The images or other third party material in this article are included in the article's Creative Commons licence, unless indicated otherwise in a credit line to the material. If material is not included in the article's Creative Commons licence and your intended use is not permitted by statutory regulation or exceeds the permitted use, you will need to obtain permission directly from the copyright holder. To view a copy of this licence, visit http://creativecommons.org/licenses/by/4.0/.

Publisher's Note Springer Nature remains neutral with regard to jurisdictional claims in published maps and institutional affiliations. 